\title{
THE EFFECT OF INTERNAL AUDIT ON FRAUD PREVENTION AT PT POS INDONESIA
}

\begin{tabular}{|c|c|}
\hline INFO ARTIKEL & ABSTRAK/ABSTRACT \\
\hline $\begin{array}{l}\text { Histori Artikel : } \\
\text { Tgl. Masuk : } 31 \text { Oktober } 2019 \\
\text { Tgl. Diterima : } 26 \text { November } 2019 \\
\text { Tersedia Online : } 23 \text { Desember } 2019 \\
\text { Keywords: } \\
\text { Internal Audit, Fraud Prevention }\end{array}$ & $\begin{array}{l}\text { To be able to manage and manage company assets } \\
\text { efficient, then management requires the function or role of } \\
\text { checking diamonds or more known as internal audit. In } \\
\text { addition, to get company property / wealth from cheating. } \\
\text { Fraud is something that must be prevented by the company } \\
\text { so that it does not happen, for that role is needed internal } \\
\text { audit in saving company assets from fraud. This research } \\
\text { tries to Knowing the implementation of internal audits, } \\
\text { overcoming fraud (fraud), and the role of the audit internal } \\
\text { fraud preven/tion efforts (Fraud) at PT Pos Indonesia } \\
\text { (Persero) Office Center of Bandung. The method used in } \\
\text { this research is survey method. Analysis Descriptive data of } \\
\text { research results using continuum analysis. Data analysis } \\
\text { using contrary to Product Moment. Hypothesis testing using } \\
\text { t test. Based on test results Obtained from the conclusion } \\
\text { that the implementation of internal audit is good, and the } \\
\text { conclusion cheating (fraud) is good. The results of the audit } \\
\text { assessment coefficient values when internal with variables } \\
\text { overcoming fraud (fraud) of 0.583, included in the category } \\
\text { of "moderate" (0.4 - 0.599). T test results indicate that } \\
\text { tcount } t \text { table (4,054> 2,037) or hypothesis is accepted. } \\
\text { With thus it can be concluded that "Internal Audit has a } \\
\text { significant role Fraud prevention efforts (fraud) at PT Pos } \\
\text { Indonesia (Persero) Bandung. }\end{array}$ \\
\hline
\end{tabular}

\section{PENDAHULUAN}

Memasuki revolusi industri generasi keempat, teknologi informasi mengalami kemajuan yang sangat pesat dan telah menjadi basis dalam kehidupan manusia (Leni Rohida, 2018), sehingga menjadi sebuah keuntungan dan kerugian bagi perusahaan sektor industri, perdagangan, maupun jasa dalam menunjang kelancaran kegiatan usaha bisnisnya. Namun saat ini permasalahan yang muncul pun semakin luas dan kompleks. Permasalahan tersebut berupa masalah yang berada di internal perusahaan maupun eksternal perusahaan.
Masalah internal perusahaan berupa kurangnya modal usaha, teknologi atau peralatan yang kurang mendukung, hubungan baik dengan para stakeholdernya (investor, supplier, kreditur, karyawan, pelanggan), sistem informasi akuntansi, kecurangan atau fraud yang dilakukan karyawan ataupun peran audit internal perusahaan yang masih belum baik dan memadai. Sedangkan pada masalah eksternal perusahaan dapat berupa kenaikan harga atau inflasi, meningkatnya tingkat suku bunga, persaingan yang semakin ketat 
dengan para pesaingnya dan lain sebagainya.

Melihat permasalahan tersebut maka perusahaan dalam melakukan kegiatan usaha bisnisnya, harus memahami segala dampak dan risiko yang akan diterimanya serta mencari berbagai macam cara dan strategi agar dapat menghadapi segala risiko dan permasalahan internal maupun eksternal, sehingga dapat menunjang kelangsungan hidup perusahaan.

Pada dasarnya, tujuan perusahaan didirikan adalah untuk memperoleh laba yang semaksimal mungkin dan tetap mempertahankan eksistensi kegiatan usaha bisnisnya dalam situasi apapun, serta diharapkan dapat berkembang dengan pesat untuk kedepannya. Untuk dapat mewujudkan tujuan perusahaan tersebut, maka salah satu caranya adalah perusahaan harus dapat mengelola harta atau kekayaan secara efektif dan efisien serta menjaganya dari segala bentuk kecurangan yang dilakukan oleh karyawannya. Pengertian fraud itu sendiri menurut (Sukanto, 2009:16) merupakan penipuan yang sengaja dilakukan, yang menimbulkan kerugian pihak lain dan memberikan keuntungan bagi pelaku kecurangan dan atau kelompoknya. Fraud dengan segala bentuk penipuan yang dilakukan telah membawa dampak buruk dan kerugian kepada organisasi bisnis (Rita Anugerah, 2014).

Fraud atau kecurangan dapat berupa penipuan yang secara sengaja dilakukan untuk mengambil hak atapun harta dari orang lain. Bentuk-bentuk dari kecurangan (fraud) yang terjadi di suatu perusahaan ataupun organisasi antara lain penyalahgunaan aset, pernyataan palsu, dan korupsi (Yulina Eliza, 2015)

Upaya untuk mencegah terjadinya fraud, perusahaan atau organisasi harus menerapkan program anti fraud yang berupa pengendalian internal, pengendalian internal merupakan proses seluruh kegiatan yang harus dilaksanakan oleh perusahaan atau organisasi (Ony Widilestariningtyas, 2014). Aktivitas pengendalian internal merupakan kegiatan atau aktivitas yang sangat penting dalam suatu perusahaan. Apabila pengendalian internal dilakukan kurang optimal akan menyebabkan penyimpangan atau kerugian bagi perusahaan (Himmatul Khoiro, et al, 2017). Untuk menghindari terjadinya penyimpangan tersebut maka diperlukan audit internal yang membantu manajemen dalam mengawasi pelaksanaan pengendalian internal (Duma Megaria Elisabeth, 2019). Dengan adanya audit internal yang memadai, segala tindakantindakan yang merugikan perusahaan akan dapat dikurangi (Ony Widilestariningtyas, 2014).

Selain itu, untuk menjaga harta atau kekayaan perusahaan dari tindakan kecurangan atau fraud maka diperlukan adanya upaya pencegahan kecurangan. Kecurangan adalah sesuatu yang harus dicegah oleh perusahaan agar tidak terjadi, untuk itu diperlukan peran audit internal dalam menjaga harta perusahaan dari kecurangan. Dalam perusahaan, internal audit harus memastikan seberapa jauh perusahaan dapat terlindungi dari kemungkinan terjadinya segala bentuk kecurangan, pencurian maupun penyalahgunaan harta atau aset perusahaan.

Di Indonesia istilah fraud atau yang lebih dikenal dengan sebutan korupsi, berkembang begitu pesat dan menyebar di segala sektor, baik pemerintahan, BUMN maupun swasta. Di sektor BUMN, salah satu perusahaan BUMN Indonesia yang telah mengalami tindakan fraud atau 
kecurangan adalah PT. Pos Indonesia (Persero). Satu dari sekian banyak perusahaan BUMN di Indonesia yang telah terjadi kasus fraud adalah PT. Pos Indonesia (Persero). Mantan SVP Operasi, VP Pengendalian Sistem Operasi dan mantan VP Kolekting dan Antaran PT Pos Indonesia dituntut hukuman penjara sekitar 18 bulan oleh jaksa penuntut umum dikarenakan ketiga pegawai tersebut telah terbukti melakukan penyalahgunaan dana tambahan pengiriman Kartu Perlindungan Sosial (KPS) di PT Pos Indonesia sebesar Rp 2,4 miliar (Supriadi, 2017).

Pada tahun 2015 juga kejaksaan agung telah membongkar kasus korupsi pengadaan alat portable data terminal (PDT) di kantor pusat PT Pos Indonesia (Persero), Kota Bandung. Dari sejumlah 1725 alat yang dibeli, hanya sejumlah 50 alat PDT yang dapat berfungsi dan alat tersebut tidak sesuai dengan spesifikasi yang tertera kontrak. Alat tersebut bentuknya menyerupai handphone yang akan digunakan oleh kurir pos untuk mengirimkan data pengiriman barang yang telah diterima pelanggan ke server pusat. Menurut BPKP, proyek tersebut diduga menyebabkan kerugian negara hingga Rp. 9,56 miliar (Rahman, 2016).

Kemudian pada tahun 2016 terdapat kasus korupsi yang dilakukan oleh pegawai Kantor Pos Cabang Muara Bungo, Kota Jambi. Pegawai tersebut yang menjabat sebagai kasir terbukti melakukan penggelapan sekitar $R p \quad 1,8$ miliar uang negara. Bukti-bukti kasus penggelapan uang negara yang dilakukan pegawai tersebut antara lain terbukti dari hasil perhitungan uang yang dilakukan oleh petugas kasir, dan surat pernyataan perhitungan uang oleh petugas kasir yang diperiksa kepala kantor Pos serta berdasarkan rekaman kamera pemantau
(CCTV) di ruang kasir Kantor Pos Bungo (Hamid, 2016).

Selain itu pada bulan mei tahun 2019 terbongkar kasus korupsi materai senilai Rp. 2.094 miliar yang dilakukan oleh staf keuangan kantor pos medan. Pegawai Kantor Pos Medan tersebut telah melakukan penjualan ribuan materai 6.000 secara langsung kepada masyarakat, namun uang dari hasil penjualan tersebut tidak dilakukan penyetoran secara penuh kepada kasir (Caroline, 2019).

Kasus tersebut di atas adalah kasus kecurangan yang terjadi di salah satu perusahaan BUMN di Indonesia. Dalam konsep segitiga kecurangan atau dikenal dengan sebutan fraud triangle, dijelaskan bahwa faktor penyebab terjadinya kasus kecurangan yaitu disebabkan oleh faktor tekanan (pressure), kesempatan (opportunity), dan rasionalisasi (rationalization). Faktor tekanan adalah dorongan yang menyebabkan seseorang melakukan kecurangan yang diakibatkan karena kebutuhan atau masalah finansial. Kedua, faktor kesempatan terjadi karena kurang efektifnya pengendalian internal. Dan ketiga, faktor rasionalisasi dimana sikap pembenaran yang dilakukan oleh pelaku dengan merasionalkan bahwa tindakan kecurangan adalah sesuatu yang wajar. (Tuanakotta, 2007).

Menurut laporan "2002 Report to Nation on Occupational Fraud and Abuses" menyatakan bahwa aktivitas internal auditor dapat menekan 35\% terjadinya fraud. Oleh karena itu, manajemen perusahaan harus mengoptimalkan peranan audit internal perusahaan sehingga audit internal mampu membantu manajemen untuk menjalankan aktivitas bisnis perusahaannya secara efektif dan efisien serta dapat mencegah terjadinya 
kecurangan. Internal audit adalah suatu penilaian, yang dilakukan oleh pengawas perusahaan yang terlatih mengenai ketelitian, dapat dipercaya, efisiensi dan kegunaan catatan-catatan (akuntansi) perusahaan, serta pengendalian intern yang terdapat dalam perusahaan. Tujuannya adalah untuk membantu manajemen dalam melaksanakan tanggungjawabnya dengan memberikan analisa, penilaian, saran, dan kegiatan yang diaudit (Soeharmoro, 2012).

\section{KERANGKA TEORITIS DAN PENGEMBANGAN HIPOTESIS}

Jensen \& Meckling (1976) mendefinisikan teori agensi sebagai hubungan antara agen (manajemen) dan principal (pemilik), manajemen sebagai agen yang bertanggung jawab untuk mengoptimalkan keuntungan para pemilik (principal). Permasalahan keagenan (agency problems) terjadi ketika adanya pemisahan fungsi kepimilikan dan pengelolaan perusahaan dimana pemilik perusahaan (principal) memberikan tugas dan tanggung jawab kepada para agen untuk mengelola perusahaan, sedangkan para manajer (manajemen) memiliki kepentingan untuk mendapatan bonus atau insentif atas pengelolaan perusahaan yang telah dilakukannya (Eka Ariaty Arfah, 2011). Manajer dalam hal ini dapat melakukan tindakan kecurangan (fraud) untuk memanipulasi laba, agar insentif atau bonus yang diberikan oleh principal semakin besar. Tindakan-tindakan memanipulasi laba tersebut yang memerlukan adanya pengendalian internal atau audit internal (Wibowo et al., 2013).

Cressey (1953) dalam teori fraud triangle mengemukakan ada tiga hal yang dapat mengakibatkan kecurangan, (1) tekanan

(Unshareable
Pressure/incentive), faktor tekanan yang dapat mengakibatkan kecurangan berasal dari keserakahan, kondisi ekonomi, dan faktor emosional, (2) peluang atau kesempatan (perceived opportunity), merupakan kondisi yang dimanfaatkan untuk melakukan kecurangan. Peluang tersebut muncul akibat lemahnya pengendalian internal, (3) rasionalisasi (rationalization), merupakan kondisi pada saat pelaku fraud tidak melakukan kecurangan. Padahal sebelumnya telah melakukan kecurangan.

Internal audit (pemeriksaan intern) adalah pemeriksaan yang dilakukan oleh bagian internal audit perusahaan, terhadap laporan keuangan dan catatan akuntansi perusahaan maupun ketaatan terhadap kebijakan manajemen puncak yang telah ditentukan dan ketaatan terhadap peraturan pemerintah dan ketentuan- ketentuan dari ikatan profesi yang berlaku. Peraturan pemerintah misalnya peraturan di bidang perpajakan, pasar modal, lingkungan hidup, perbankan, perindustrian, investasi, dan lain-lain (Sukrisno Agoes, 2012). Internal audit atau pemeriksaan internal juga dapat dikatakan sebagai suatu fungsi penilaian yang independen dalam suatu organisasi untuk menguji dan mengevaluasi kegiatan organisasi yang dilaksanakan (Hiro Tugiman, 2011).

Peranan auditor internal dalam perusahaan (Sawyer, 2009) adalah sebagai berikut :

1. Mengawasi kegiatan-kegiatan yang tidak dapat diawasi sendiri oleh manajeman puncak.

2. Mengidentifikasi dan meminimalkan risiko

3. Memvalidasi laporan ke manajemen senior

4. Membantu manajemen pada bidangbidang teknis. 
Fraud dapat diistilahkan sebagai kecurangan yang mengandung makna suatu penyimpangan dan perbuatan melanggar hukum (illegal act), yang dilakukandengan sengaja untuk tujuan tertentu misalnya menipu atau memberikan gambaran keliru (mislead) kepada pihakpihak lain, yang dilakukan oleh orang- orang baik dari dalam maupun dari luar organisasi. Kecurangan di rancang untuk memanfaatkan peluang-peluang secara tidak jujur, yang secara langsung maupun tidak langsung merugikan pihak lain (Karyono,2013). Fraud juga dapat dikatakan sebagai suatu pengertian umum dan mencakup beragam cara yang dapat digunakan oleh kecerdikan manusia, yang digunakan dengan cara kekerasan oleh seseorang, untuk mendapatkan suatu keuntungan dari orang lain melalui perbuatan yang tidak benar (Tunggal, 2012).

Kecurangan yang mungkin terjadi harus dicegah antara lain dengan cara cara berikut (Amrizal, 2004:5-11) :

1. Membangun struktur pengendalian yang baik.

2. Mengefektifkan aktivitas engendalian
a. Review kinerja
b. Pengolahan informasi
c. Pengendalian fisik
d. Pemisahan tugas

3. Meningkatkan kultur organisasi

Meningkatkan kultur organisasi dapat dilakukan dengan cara melakukan implementasi prinsip-prinsip Good Corporate Governance (GCG).

4. Mengefektifkan fungsi internal audit Walaupun internal auditor tidak dapat menjamin bahwa kecurangan tidak akan terjadi, namun ia harus menggunakan kemahiran jabatannya dengan seksama sehingga diharapkan mampu mendeteksi terjadinya kecurangan dan dapat memberikan saran-saran yang bermafaat kepada manajemen untuk mencegah terjadinya kecurangan.

5. Menciptakan struktur penggajian yang wajar dan pantas.

6. Mengadakan rotasi dan kewajiban bagi pegawai untuk mengambil hak cuti.

7. Memberikan sanksi yang tegas kepada yang melakukan kecurangan dan berikan penghargaan kepada mereka yang berprestasi.

8.Membuat program bantuan kepada pegawai yang mendapatkan kesulitan baik dalam hal keuangan maupun non keuangan.

9. Menetapkan kebijakan perusahaan terhadap pemberian-pemberian dari luar harus diinformasikan dan dijelaskan pada orang-orang yang dianggap perlu agar jelas mana yang hadiah dan mana yang berupa sogokan dan mana yang resmi.

10. Menyediakan sumber-sumber tertentu dalam rangka mendeteksi kecurangan karena kecurangan sulit ditemukan dalam pemeriksaan yang biasa-biasa saja.

11. Menyediakan saluran saluran untuk melaporkan telah terjadinya kecurangan hendaknya diketahui oleh staf agar dapat diproses pada jalur yang benar.

Menurut Sugiyono (2015:93) pengertian hipotesis adalah sebagai berikut :

"Hipotesis merupakan jawaban sementara terhadap rumusan masalah penelitian, oleh karena itu rumusan masalah penelitian biasanya disususn dalam bentuk kalimat pertanyaan".

Berdasarkan uraian tersebut, maka penulis mengemukakan hipotesis penelitian sebagai berikut: "Audit internal memiliki pengaruh dalam upaya pencegahan kecurangan (fraud) pada PT 
Pos Indonesia (Persero) Kantor Pusat Bandung.

Hipotesis yang dimunculkan dalam penelitian ini yaitu:

$\mathrm{HO}$ : Audit internal (X) tidak memiliki pengaruh dalam upaya pencegahan kecurangan (Y) pada PT Pos Indonesia (Persero) Kantor Pusat Bandung.

$\mathrm{Ha}$ : Audit internal $(\mathrm{X})$ memiliki pengaruh dalam upaya pencegahan kecurangan (Y) pada PT Pos Indonesia (Persero) Kantor Pusat Bandung.

\section{METODOLOGI PENELITIAN}

Objek dalam peneltian ini adalah peranan audit internal dan pencegahan fraud yang dilakukan pada Kantor Pusat PT. Pos Indonesia (Persero) Kota Bandung. Metode dalam penelitian ini adalah metode survey dengan pendekatan metode deskriptif.

Populasi dalam penelitian ini adalah karyawan Kantor Pusat PT Pos Indonesia (Persero) sebagai berikut :

1. Bagian Satuan Pengawasan Intern (SPI) sebanyak 12 orang.

2. Bagian Governance, Risk, dan Compliance sebanyak 7 orang.

3. Bagian Hukum sebanyak 10 orang.

4. Bagian Penelitian \& Pengembangan 5 orang.

Sehingga jumlah Populasi sebanyak 34 orang. Sedangkan yang menjadi sampel dalam penelitian ini adalah seluruh anggota populasi, dikarenakan jumlah populasi dalam penelitian ini sedikit sehingga jumlah sampel sama dengan jumlah populasi yaitu sebanyak 34 orang.

Sedangkan untuk teknik analisis data yang digunakan dalam penelitian ini adalah analisis deskriptif, uji normalitas dan uji beda.
Dalam teknik pengumpulan data yang dilakukan dalam penelitian ini adalah penelitian lapangan yang terdiri atas penyampaian kuesioner, wawancara, dan observasi. Juga dilakukan studi kepustakaan. data yang dipergunakan merupakan sumber data primer dan sumber data sekunder. sumber data primer berasal dari sumber pertama dan sumber sekunder didapatkan dari studi kepustakaan.

Dalam teknik analisis data dipergunakan analisis deskriptif yang berasal dari pengumpulan data melalui kuesioner tertutup dan alternatif jawaban dengan skala likert. Sedangkan untuk menganalisa data mempergunakan regresi linear sederhana dengan persamaan: $Y=\alpha+\beta x$.

Untuk pengujian hipotesis digunakan adalah uji t. Dimana : 1. Ho ditolak, Ha diterima: apabila -t tabel > -t hitung atau t hitung $>\mathrm{t}$ tabel.

2. Ho diterima, Ha ditolak: apabila -t tabel $<-t$ hitung atau $t$ hitung $<\mathrm{t}$ tabel

\section{HASIL DAN PEMBAHASAN}

Secara keseluruhan pada variabel Pelaksanaan Audit Internal dengan jumlah item pernyataan 10 butir, diperoleh total skor sebesar 1408 dan nilai rata- rata hitung sebesar 4.14. Sehingga dapat diketahui bahwa tanggapan responden tehadap 10 butir pernyataan yang diajukan mengenai Pelaksanaan Audit Internal termasuk dalam kategori baik. Hal ini menunjukkan bahwa pemeriksaan yang dilakukan oleh bagian internal audit di PT Pos Indonesia (Persero) Kantor Pusat Bandung dinilai baik dalam laporan keuangan dan catatan akuntansi maupun ketaatan terhadap kebijakan manajemen puncak, ketaatan terhadap peraturan pemerintah dan ketentuan-ketentuan dari ikatan profesi yang berlaku. 
Secara keseluruhan pada variabel Pencegahan Kecurangan dengan jumlah item pernyataan 10 butir, diperoleh total skor sebesar 1.295 dan nilai rata-rata hitung sebesar 3.81. Sehingga dapat diketahui bahwa tanggapan responden tehadap 10 butir pernyataan yang diajukan mengenai Pencegahan Kecurangan termasuk dalam kategori baik. Hal ini menunjukkan bahwa pecegahan kecurangan yang dilakukan dengan sengaja untuk tujuan tertentu yang dilaksanakan untuk mengevaluasi efisiensi dan efektivitas dari aktivitas perusahaan yang telah dilaksanakan pada periode waktu tertentu PT Pos Indonesia (Persero) Kantor Pusat Bandung menurut responden dinilai baik.

Hal ini terlihat dari pelaksanaan unsurunsur standar professional audit internal yaitu independensi, kemampuan profesional, lingkup pekerjaan, pelaksanaan tugas audit internal dan manajemen audit internal yang mendapatkan skor rekapitulasi atas tanggapan responden sebesar 1.408 dengan nilai rata-rata hitung sebesar 4.14 sehingga masuk dalam kategori baik. Adanya tanggapan responden yang memberikan nilai sebesar 1.408 dengan nilai rata-rata hitung 4.14 menunjukkan suatu pemenuhan unsur-unsur standar profesional audit internal. Setiap komponen audit internal di PT. Pos Indonesia memiliki kesadaran untuk melakukan kegiatan audit dengan dilandasai unsur-unsur standar profesional audit internal yang ada.

Pencegahan Kecurangan (fraud) pada Kantor Pusat PT Pos Indonesia (Persero) telah dilaksanakan dengan baik. Hal ini terlihat dari unsur-unsur pencegahan kecurangan yaitu membangun struktur pengendalian, meningkatkan kultur organisasi, menciptakan struktur penggajian yang wajar \& pantas, mengadakan rotasi \& kewajiban bagi pegawai untuk mengambil hak cuti dan memberikan sanksi yang tegas kepada pegawai yang melakukan kecurangan \& memberikan penghargaan kepada mereka yang berprestasi yang mendapatkan skor rekapitulasi atas tanggapan responden sebesar 1.295 dengan nilai rata-rata hitung sebersar 3.81 sehingga masuk dalam kategori baik. Dengan tanggapan yang dimunculkan oleh responden sedemikian rupa maka terlihat bahwa terdapat kesadaran adanya potensi kecurangan yang dapat terjadi di dalam suatu perusahaan. Maka dengan adanya kesadaran atas potensi kecurangan tersebut dilakukan langkahlangkah untuk mencegah munculnya kecurangan tersebut. langkah-langkah tersebut sebagaimana disebutkan diatas seperti membangun struktur pengendalian, meningkatkan kultur organisasi, menciptakan struktur penggajian yang wajar \& pantas, mengadakan rotasi \& kewajiban bagi pegawai untuk mengambil hak cuti dan memberikan sanksi yang tegas kepada pegawai yang melakukan kecurangan \& memberikan penghargaan kepada mereka yang berprestasi

terkait dengan pengujian hipotesi maka berdasarkan perhitungan hasil uji t, nilai t hitung (4.054) lebih besar dari t kritis (2.037) dan berada pada daerah penolakan. Karena nilai thitung lebih besar dibanding kritis dan nilai p-value (Sig.) yang diperoleh sebesar 0,000 lebih kecil dari 0,05 ( $\alpha=5 \%)$ maka $\mathrm{HO}$ ditolak dan $\mathrm{Ha}$ diterima. Dengan demikian maka hipotesis alternatif yang menyatakan bahwa Audit internal $(X)$ memiliki peranan dalam upaya pencegahan kecurangan ( $\mathrm{Y}$ ) pada PT Pos Indonesia (Persero) Kantor Pusat Bandung dapat diterima yang memiliki makna bahwa audit internal yang 
dijalankan dalam suatu perusahaan akan memberikan dampak positif dalam pencegahan kecurangan. dampak positif ini dapat terjadi jika unsur-unsur standar profesionalitas audit internal dan unsurunsur pencegahan kecurangan (fraud) terpenuhi dengan baik

\section{KESIMPULAN}

Berdasarkan hasil penelitian dan pembahasan masalah pada uraian sebelumnya, maka penulis dapat memberikan kesimpulan bahwa:

1. Audit internal pada Kantor Pusat PT Pos Indonesia (Persero) telah dilaksanakan dengan baik. Hal ini terlihat dari pelaksanaan unsur-unsur standar professional audit internal di PT. Pos Indonesia yang memberikan nilai tanggapan responden dengan kategori baik

2. Pencegahan Kecurangan (fraud) pada Kantor Pusat PT Pos Indonesia (Persero) telah dilaksanakan dengan baik. Hal ini terlihat dari unsur-unsur pencegahan kecurangan internal di PT. Pos Indonesia yang memberikan nilai tanggapan responden dengan kategori baik

3. Berdasarkan nilai uji $t$ yang menghasilkan nilai t hitung lebih besar dari nilai $\mathrm{t}$ kritis maka $\mathrm{HO}$ ditolak dan $\mathrm{Ha}$ diterima sehingga hipotesis alternatif yang menyatakan bahwa Audit internal (X) memiliki pengaruh dalam upaya pencegahan kecurangan (Y) pada $\mathrm{PT}$ Pos Indonesia (Persero) Kantor Pusat Bandung dapat diterima

\section{Saran}

Berdasarkan hasil penelitian dan kesimpulan diatas maka saran dalam penelitian ini adalah:

1. indikator pelaksanaan tugas audit internal di PT. Pos Indonesia termasuk dalam kategori baik. Meski demikian jumlah skor dan nilai rata-rata paling kecil jika dibandingkan indikator pelaksanaan audit internal lainnya. Oleh Karena itu, Pihak Kantor Pusat PT Pos Indonesia Bandung harus lebih memperhatikan dengan baik dan mengevaluasi kembali indikator audit internal dalam segi pelaksanaan tugas audit internal guna meningkatkan efektifitas pelaksanaan audit internal di Kantor Pusat PT Pos Indonesia Bandung.

2. Pada indikator mengadakan rotasi dan kewajiban bagi pegawai untuk mengambil hak cuti termasuk dalam kategori baik, meskipun demikian, jumlah skor dan nilai rata-rata tersebut juga paling kecil diantara indikator pencegahan kecurangan lainnya. Oleh karena itu, Kantor Pihak Pos Indonesia Bandung harus lebih memperhatikan dengan baik dan mengevaluasi kembali indikator pencegahan kecurangan dalam segi mengadakan rotasi dan kewajiban bagi pegawai untuk mengambil hak cuti guna meningkatkan efektifitas pencegahan kecurangan di Kantor Pusat PT Pos Indonesia Bandung.

\section{IMPLIKASI DAN KETERBATASAN}

Penelitian ini menguji Pengaruh Audit Internal terhadap Pencegahan Fraud Pada PT Pos Indonesia. Hasil Penelitian menunjukkan bahwa pelaksanaan audit internal dan pencegahan kecurangan pada perusahaan sudah termasuk dalam kategori baik, Sehingga dapat disimpulkan bahwa Audit Internal memiliki peranan dalam Upaya Pencegahan Kecurangan (fraud) pada Kantor Pusat PT. Pos Indonesia (Persero) Bandung.

Meski demikian, Penelitian ini memiliki keterbatasan penelitian yang dapat mempengaruhi hasil penelitian, adalah sebagai berikut: 
1. PT. Pos indonesia merupakan suatu perusahaan BUMN terbesar dengan cakupan wilayah kerja dan kantor cabang yang tersebar di seluruh Indonesia sehingga terdapat keterbatasan dari peneliti untuk dapat melakukan penelitian atas proses audit internal dan pencegahan fraud di seluruh cabang PT. Pos Indonesia.

2. Berhubung PT Pos Indonesia merupakan salah satu perusahaan BUMN Terbesar di Indonesia, Penelitian selanjutnya di harapkan meneliti kembali kasus kecurangan yang ada di PT Pos Indonesia di luar Kantor Pusat Bandung. $\mathrm{Hal}$ ini disebabkan karena banyak kasus kecurangan terjadi di luar lokasi penelitian.

\section{DAFTAR PUSTAKA}

Agoes, Sukrisno. (2012). Auditing Petunjuk Praktis Pemeriksaan Akuntan oleh Akuntan Publik Jilid I Edisi Keempat. Salemba Empat, Jakarta

Amrizal (2004). Pencegahan dan Pendeteksian Kecurangan oleh Internal Audit. BPKP, Jakarta.

Anugerah, Rita (2014). Peranan Good Corporate Governance dalam Pencegahan Fraud, Jurnal Akuntansi, Vol 3, No.1, Oktober 2014 : 101 - 113. ISSN 2337-4314

Cressey, D.R. (1953). Other People's Money: a study in the social psychology of embezzlement. Glencoe, IL: The Free Press.

Damanik, Caroline. (2019) https://medan.kompas.com/read/201 9/05/06/12265341/pegawai-kantorpos-diduga-korupsi-materai-rp-2$\underline{\text { miliar-beraksi-dua-tahun?page=all }}$ diakses pada Sabtu 19 Oktober 2019 jam 16:00.

Elisabeth, Duma Megaria (2019). Analisis Fungsi dan Tujuan Internal Auditor dalam Pelaksanan Pengendalian Intern Untuk Memaksimalkan Kinerja Perusahaan (Studi Kasus pada Salah Satu BUMN di Kota Medan). Jurnal Akuntansi dan Keuangan Methodist. Vol. 2 No.2, 2019, 131-140. ISSN 2599-0136

Eliza, Yulina. (2015). Pengaruh Moralitas Individu dan Pengendalian Internal Terhadap Kecenderungan Kecurangan Akuntansi (Studi Empiris Pada SKPD di Kota Padang, Jurnal Akuntansi, Vol. 4, No. 1, Oktober 2015 : 86-100. ISSN 2337-4314

Hamid (2016), Polres Bungo Tahan Karyawan Kantor Pos Tersangka Kasus Dugaan Korupsi https://metrojambi.com/read/2016/01/ 08/6714/polres-bungo-tahankaryawan-kantor-pos-tersangkakasus-dugaan-korupsi- diakses pada Sabtu 19 Oktober 2019 jam 18:40.

Jensen, M.C., \& Meckling, W.H., (1976). Theory of The Firm: Managerial Behavior, Agency Costs, and Ownership Structure. Journal of Financial Economics, 3, 305-360.

Karyono. (2013). Forensic Fraud. Penerbit ANDI : Yogyakarta.

Khoiro, Himmatul, (2017). Peranan Audit Internal Terhadap Kepatuhan Manajemen Perusahaan Pada PT. Hero Supermarket Tbk. Waru Sidoarjo, Jurnal Ekonomi Akuntansi Vol 3. Issue. 32017.

Rahman, Ainur (2016), Mengungkap Borok Korupsi PT Pos Indonesia http://www.gresnews.com/berita/huku m/108710-mengungkap-borok-korupsi- 
pt-pos-indonesia/ diakses pada Sabtu 19 Oktober 2019 jam 18:50.

Rohida, Leni. (2018). Pengaruh Era Revolusi Industri 4.0 terhadap Kompetensi Sumber Daya Manusia, Vol.6 Nomor 1, Jurnal Manajemen Bisnis Indonesia.

Sugiyono. (2015). Metode Penelitian Pendidikan : Pendekatan Kuantitatif, Kualitatif dan R\&D. Alfabeta Bandung.

Supriadi, Yedi (2017). Korupsi Bersamasama Para Mantan Pejabat PT Pos Dituntut 18 Bulan Penjara. Sumber: https://www.pikiranrakyat.com/bandungraya/2017/06/05/korupsi-bersamasama-para-mantan-pejabat-pt-posdituntut-18-bulan-penjara diakses pada Sabtu 19 Oktober 2019 jam 17:05.

Sukanto, Eman. (2009). Perbandingan persepsi Auditor Internal, Akuntan Publik, dan Auditor Pemerintah terhadap Penugasan Fraud Audit dan Profil Fraud Auditor. Fokus Ekonomi: Vol 4. No. 1 Juni 2009.

Soeharmoro, (2012). Peran Internal Auditor Dalam Pendekteksian dan Pencegahan Kecurangan. Jurnal Berkala IImiah Akuntansi. Vol 1 No.3 Mei 2012. 7-11.

Sawyer, Lawrence B, Dittenhofer Mortimer A, Scheiner James H, (2009). Internal Auditing, Diterjemahkan oleh: Desi Adhariani, Jilid 1, Edisi 5, Salemba Empat, Jakarta.

Tuanakotta, Theodorus. (2007). Akuntansi Forensik dan Audit Investigatif. Edisi II, Salemba Empat, Jakarta.
Tugiman, Hiro (2011). Pandangan Baru Internal Auditing. Kanisius, Yogyakarta.

Tunggal, Amin Widjadja. (2013). The Fraud Audit: Mencegah dan Mendeteksi Kecurangan Akuntansi, Harvarindo, Jakarta.

Widilestariningtyas, Ony. (2014). Pengaruh Audit Internal Terhadap Risiko Fraud (Survey Pada PT. Bank Rakyat Indonesia di Wilayah Bandung), Jurnal Riset Akuntansi, Vol VI, No 1. April 2014. ISSN : 2086-0447 